日植病報 $33: 48 \sim 58$ (1967)

Ann. Phytopath. Soc. Japan $33: 48 \sim 58$ (1967).

\title{
The Role of Phenolic Compounds in the Resistance of Potato Tuber Tissue to Infection by Phytophthora infestans.
}

\author{
Tsutomu SAKuma* and Kohei Tomiyama* \\ 佐久間勉*, 冨山宏平* : ジャガイモ塊茎の疫病抵抗性に括ける \\ フェノール化合物の意義について
}

\begin{abstract}
1. Potato tuber disks, $0.5 \mathrm{~mm}$ thick, of a variety having a resistance gene (R) became susceptible when inoculated with a dense spore suspension of an incompatible race of Phytophthora infestans.

2. Treatment of these susceptible disks with phenolic compounds, such as chlorogenic acid, guaiacol, hydroquinone, catechol and caffeic acid alone or in combination with ascorbic acid, restored their resistance. Ascorbic acid by itself also reduced spore production on treated disks at the same concentration as that of chlorogenic acid.

3. Treatment with chlorogenic acid or ascorbic acid at concentrations that strongly reduced sporulation on disks infected by an incompatible race had little effect on disks infected by a compatible race of $P$. infestans.

4. Toxicities of the phenolic compounds and ascorbic acid to the pathogen were weak as compared to their inhibitory action on fungal development in the disks infected by an incompatible race.

5. It was concluded that common phenolic compounds (and possibly ascorbic acid when oxidized) which can be found in healthy plants constitute a part of the mechanism confining the invading parasite to the infected locus.

6. Analyses of the phenolic compounds contained in the potato tuber tissue infeted by an incompatibe race suggested that they may be supplied from the adjacent tissue where phenolic synthesis may be accelerated.
\end{abstract}

(Received August 6, 1966)

\section{Introduction}

Interest of researchers in the field of disease resistance physiology has been centered around phenolic compounds for a long time. However, no direct evidence that common phenolic compounds, which are found in healthy plants, directly related to the resistance of plants has been obtained in spite of the great many experimental results suggesting such a relationship ${ }^{4,17,20)}$. Accordingly, it is not unreasonable that the success of the phytoalexin theory in this field of physiology has lead some researchers to serious doubt whether common phenolic compounds could be really related to disease resistance. One of the most important arguments against their participation in disease resistance is that phenolic compounds contained in healthy plants, especially chlorogenic acid, are not necessarily toxic to pathogens at the concentrations in the living plant. The experi-

* Hokkaido National Agricultural Experiment Station, Hitsujigaoka, Sapporo, Japan. 北海道農 業試験場 
ments reported here were done to present direct evidence that phenolic compounds, especially chlorogenic acid, do play a role in the resistance of the potato tuber to infection by Phytophthora infestans. The term "common phenolic compounds" will be used in this paper to mean those found in healthy plants. Phytoalexins of phenolic nature are not included.

\section{Methods and Materials}

Plant material. The potato varieties, Kennebec (resistant) and Irish cobbler (susceptible) were used. The former variety, having the $\mathrm{R}_{1}$-gene, is almost immune to race 0 of $P$. infestans, the race used throughout these experiments. The cells of Kennebec react hypersensitively to invasion by the parasite. Cells of the latter variety, compatible to the race 0 , can survive at least 3 days or more after being intruded upon by the parasite. In some experiments the resistant variety Rishiri with the $R_{1}$-gene was used. This variety has a much greater "field resistance" than does Kennebec.

Potato tubers were stamped out using a cork borer $(2.2 \mathrm{~cm}$ dia. $)$ and cut into disks $0.5 \mathrm{~mm}$ in thickness with a microtome. The disks were briefly washed in running water, and then placed on blotting paper in a large Petri dish.

Technique Inoculation. A zoosporangia suspension was obtained from fungal mats of race 0 of $P$. infestans grown on the cut surfaces of potato tubers. These were washed twice by centrifugation at $1000 \mathrm{rpm}$. The suspension was then allowed to germinate at $11-12^{\circ} \mathrm{C}$. It was diluted to a definite concentration of spores using a haemacytometer so that one microscopic field of a Thoma haemacytometer contained 15 18 zoospores in the case of Kennebec and $5 \sim 7$ with Irish cobbler. One drop of this suspension was placed on one side of a disk and was spread over the whole surface with a glass rod. The disks were then placed in an incubator at about $18^{\circ} \mathrm{C}$ in the dark.

Twelve inoculated or uninoculated disks were dipped in $15 \mathrm{ml}$ of chemical solution for treatment in a beaker of about $100 \mathrm{ml}$ volume at $20^{\circ} \mathrm{C}$ for 30 minutes. The treated disks were again placed in a Petri dish in an incubator at $18^{\circ} \mathrm{C}$ in the dark.

One difficulty encountered in performing the experiments is the frequent occurrence of bacteria on inoculated slices. To avoid this trouble, various precautions were employed, e.g. using good zoospore suspensions, sterilizatin of the tuber-skin before experiments, and maintainance of appropriate humidity around the disks after treatment.

Chemicals used. Chlorogenic acid (extracted from coffee beans and repeatedly recrystallized), guaiacol (Kanto chemical CO., G. R.), catechol (Kanto chemical CO., G.R.), hydroquinone (recrystallized), caffeic acid (Tokyo Kasei CO., G. R.), L-tyrosine (Nippon Rika, OC. G. R.), Lascorbic acid (Kanto chemical CO., G. R.), D-glucose (Kanto chemical CO., G. R.), L-cysteine (Kanto chemical CO., G.R.) and glysine (Wako chem. CO., G. R.). These chemicals were dissolved in $0.02 \mathrm{M}$ phosphate buffer at $\mathrm{pH}$ 5.6. Infected control disks were treated with buffer alone. If necessary, the $\mathrm{pH}$ was adjusted to $\mathrm{pH} 5.6$ with $\mathrm{NaOH}$ after addition of the chemicals.

Evaluation of degree of disease resistance. The degree of disease resistance was estimated by two methods. In the first method, the shape and color of the infected lesions were used as criteria, assuming that the smaller and the darker the diseased spot, the higher the degree of resistance. In the second method, the number of spores produced on the disks was determined either 4 days after inoculation (with the susceptible variety) or 5 days (with resistant variety). Six disks were washed with $2 \mathrm{ml}$ of water, and the number of spores in the rinsing was counted 
under a microscope by using Thoma haemacytometer, giving the total number of spores produced on a disk. To assay the chemicals for their effect on zoospore germination, one drop (0.04-0.05 $\mathrm{ml}$ ) of each chemical solution ( $\mathrm{pH}$ 5.6) prepared in the same way as for the treatment of the disks was placed on a slide glass. A drop of zoospore suspension of the race 0 was put on the slide glass, and incubated at $18^{\circ} \mathrm{C}$ for $16-18$ hours.

Extraction and estimation of phenolic compounds. Materials used for analyzing phenols were prepared as follows: After cutting the potato tubers into 2 or 3 pieces, the zoospore suspension was sprayed over the cut surface. The concentration of zoospore suspension was $120 /$ microscopic field (Olmpus $15 \times 10$ ) for the Rishiri variety, and 90 for Kennebec. Tissue plugs were cut from the central parenchyma of the potato tuber at right angles to the cut surface (either infected or uninfected) with a cork borer $2.2 \mathrm{~cm}$ in diameter a definite time after inoculation. These plugs were sectioned with a microtome into disks $0.5 \mathrm{~mm}$ in thickness, starting from the cut surface and progressing toward the inner tissue. These disks successively named first layer (1-L), second layer (2-L) and so on, were used for analysis. Each layer was composed of about cells in depth. An appropriate number of the disks were weighed and ground in a mortar with sea sand and 3 volumes of $95 \%$ ethanol. The homogenate was kept in a cold room for 1 hour, then centrifuged. The precipitate was washed with $5 \mathrm{ml}$ of $80 \%$ ethanol and recentrifuged. Both of the supernatants were combined and used for further analysis. The total phenol content was determined photoelectrically by the Folin-Denis reagent ${ }^{7)}$. The values obtained were corrected by subtracting the O.D. values corresponding to the amounts of ascorbic acid contained in the alcohol extract. The ascorbic acid was estimated photoelectrically by the indophenol dye method ${ }^{5)}$ The ethanol extracts were analyzed for o-diphenols using the Arnow reagent ${ }^{2)}$. In these analyses, chlorogenic acid was used as a standard for calculating total phenols.

To determine the content of chlorogenic acid, caffeic acid and tyrosine, 10\% neutral lead acetate $(18 \mathrm{ml} / 50 \mathrm{~g}$ sample) was added to the ethanol extracts. They were then placed in a cold room for 1 hour. After centrifugation, the lead polyphenolate was suspended in a small amount of water, and the $\mathrm{pH}$ adjusted to $\mathrm{pH} 2.0$ with $10 \%$ sulfuric acid. The precipitation was collected by filtration through Tokyo No. 3 filter paper. After extracting the filtrate 5 times with an equal volume of ethyl acetate, the extracts were condensed under vacuum. Chlorogenic acid and caffeic acid were separated by ascending chromatography on sheets of Whatman No. 1 paper. The solvent used was $\mathrm{n}$-butanol-acetic acid-water $(4: 1: 5)$. The spots on the developed chromatograms were eluted with $75 \%$ ethanol. The extract was photoelectrically determined for chlorogenic and caffeic acid by the method of Zucker and Ahrens ${ }^{22)}$. Standard curves were determined using chlorogenic and caffeic acids.

The supernatant obtained from the ethanol extracts by precipitation of the polyphenols by a neutral lead acetate was used for tyrosine analysis. The lead was removed by hydrogen sulphide, and the supernatant condensed to an appropriate volume. The condensates were separated by ascending chromatography on sheets of Toyo No. 51 paper. The tyrosine extracts from the spots were estimated photoelectrically by means of the Folin-Denis reagent. The extinction curve was constructed by treating known amounts of tyrosine. Ascorbic acid was extracted with $6 \%$ metaphosphoric acid and determined by the indophenol dye method ${ }^{5)}$.

\section{Results}

Treatment of infected disks with phenolic compounds. The result was the same as reported 
Table. 1. Effect of treatment with chlorogenic acid, ascorbic acid, and their mixture on percentage sporulation of the thin disks infected by race $\mathrm{O}$ of $P$. infestans and their effect on growth rate of germ tubes of zoospores of $P$. infestans.

\begin{tabular}{c|c|c|c|c|c|c}
\hline \multirow{2}{*}{ Treatment } & \multicolumn{3}{|c|}{ spore production* } & \multicolumn{2}{c}{ growth rate of germtubes** } \\
\cline { 2 - 7 } & $0.01 \mathrm{M}$ & $0.02 \mathrm{M}$ & $0.03 \mathrm{M}$ & $0.01 \mathrm{M}$ & $0.03 \mathrm{M}$ & $0.05 \mathrm{M}$ \\
\hline Chlorogenic acid & 97 & 54 & 42 & 74 & 65 & 59 \\
L-Ascorbic acid & 87 & 57 & 58 & 86 & 71 & 48 \\
Chlorogenic acid & 77 & 55 & 32 & 75 & 62 & 53 \\
+Ascorbic acid & & & & & & \\
\hline
\end{tabular}

Remarks :
1) * The number of spores formed on the thin disks treated with phosphate buffer solution at $\mathrm{pH} 5.6$ was taken as $100 \%$.

2) ** As \% length of zoospore germtubes of $P$. infestans in $0.02 \mathrm{M}$ phosphate buffer at $\mathrm{pH} 5.6$.

3) Treatment with the chemicals was done 24 hours after inoculation.

4) The variety used was Kennebec.

in a previous paper ${ }^{18)}$. Many spores formed on the $0.5 \mathrm{~mm}$ disks, but few on the 1.0 $\mathrm{mm}$ ones. (Fig. 6). The disks used in all experiments to be described hereafter were $0.5 \mathrm{~mm}$ in thickness.

An hour before inoculation, or 8 or 24 hours after inoculation, the disks were treated with a mixture of chlorogenic and ascorbic acid in equimolar concentrations. Spore production of the disks treated 24 hours after inoculation is shown in Figures 1 and 5 . On disks of the variety Kennebec, sporulation was markedly reduced by treatment with the mixture of chlorogenic and ascorbic acid. The effect of the treatment done 1 hour before or 8 hours after inoculation was similar to that shown in Figure 1. With Irish Cobbler (susceptible), on the

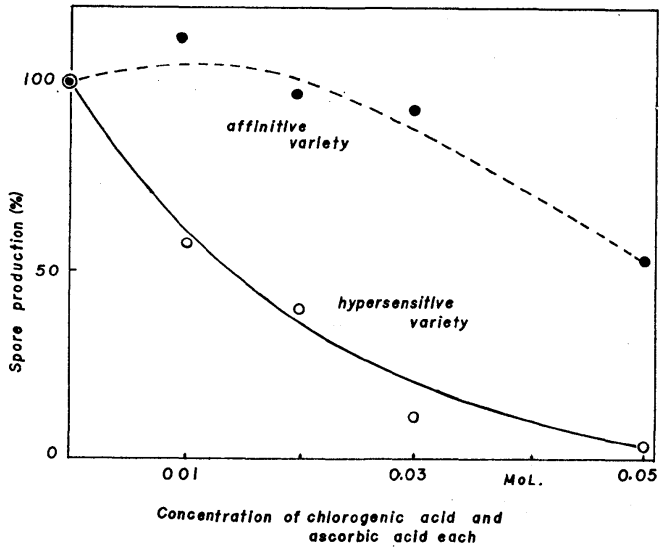

Fig. 1 Effect of mixture of chlorogenic and ascorbic acid on the spore production on disks of a susceptible variety (Irish Cobbler) and a hypersensitive variety (Kennebec) infected by race o of $P$. infestans.

contrary, little effect was noticed at the lower concentration of the mixture which had such a marked effect on the disks of the Kennebec (Fig. 1).

In other experiments, chlorogenic acid and ascorbic acid were separately tested for their inhibitory effect on sporulation on the disks (Table 1). Both compounds were inhibitory to sporulation on the infected disks of Kennebec. Ascorbic acid, however, did not reduce the sporulation on infected Irish cobbler slices.

Other phenolic compounds, guaiacol, hydroquinone, and catechol in coexistence with ascorbic acid in equimolar concentrations and caffeic acid by itself were shown to be inhibitory to spore production on Kennebec disks infected by race 0 (Figs. 2 and 3). In these cases, the concentration of ascorbic acid was so low (except with chlorogenic acid) that the inhibitive action of the mixture may be attributable entirely to the phenolic compounds. Disks infected by the incompatible race were treated with a caffeic acid solution at $0.005 \mathrm{M}$ for 15 minutes 24 hours after inoculation. The treatments were repeated several times at 30 minutes intervals, to attain to 

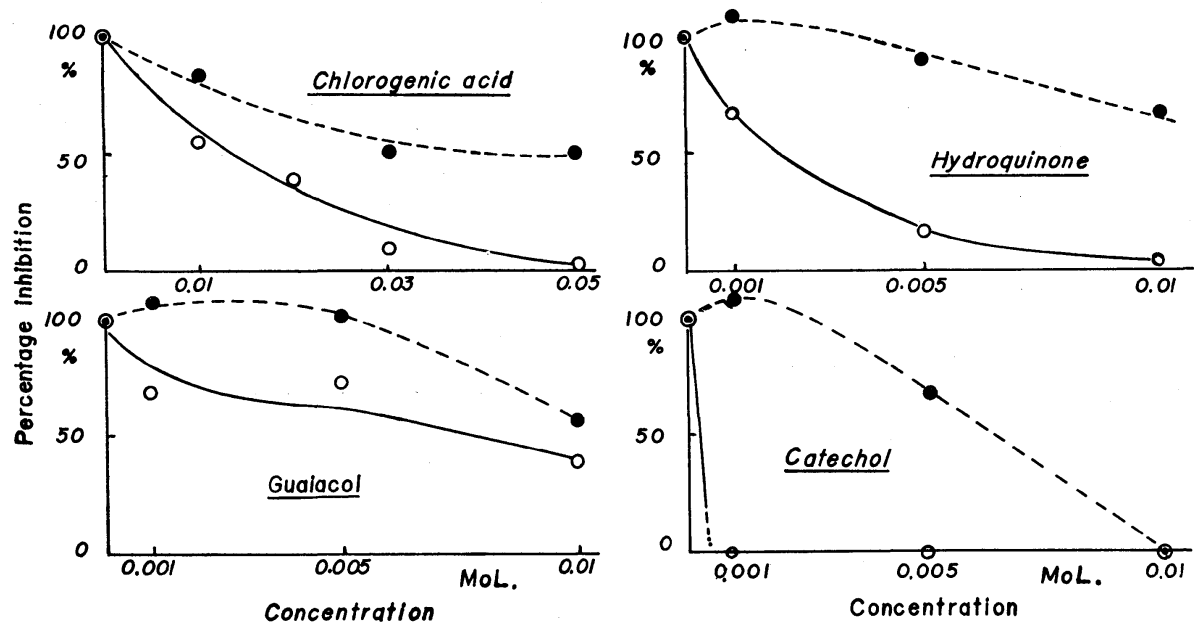

Fig. 2. Effect of some phenolic compounds on the spore production on thin disks infected by an incompatible race of $P$. infestans (-O-) and zoospore germination. $(\cdots \bullet \cdots)$. Ascorbic acid was added to each of the phenolics in equimolar concentration.

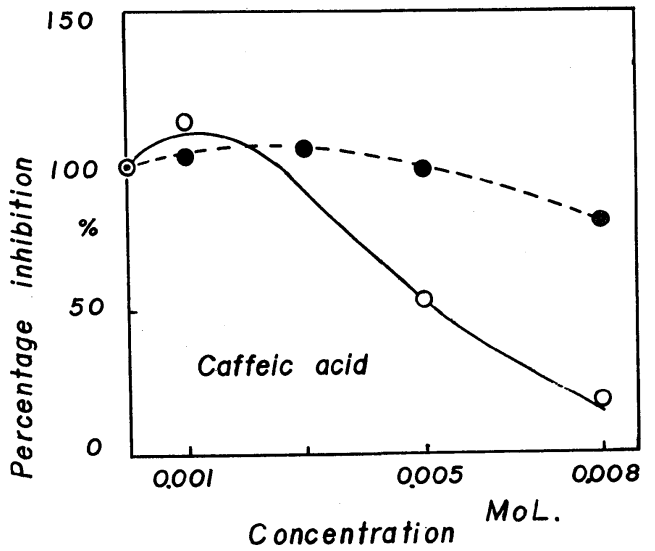

Fig. 3. Effect of caffeic acid on spore production on thin disks infected by an incompatible race of $P$. infestans (-O-) and zoospore germination $(\cdots \bullet \cdots)$. Ascorbic acid was not added.
Table 2. Effect of caffeic acid on the spore production of thin potato-tuber disks infected by an incompatible race of $P$. infestans.

\begin{tabular}{l|r|r|r}
\hline $\begin{array}{l}\text { Number of repetition } \\
\text { of treatment }\end{array}$ & \multicolumn{1}{c|}{1} & \multicolumn{1}{c|}{3} & \multicolumn{1}{c}{5} \\
\hline Caffeic acid(0.005 Mol) & 97.6 & 52.8 & 36.6 \\
Cont. (Buffer) & 100 & 100.0 & 100.0 \\
\hline
\end{tabular}

higher concentration of caffeic acid in the treated slices. The results obtained are shown in Table 2. Repetition of the caffeic acid treatment was shown to increase the inhibitive effect on the spore production on infected disks. Tyrosine was saturated in the phosphate buffer solution (about $0.002 \mathrm{M}$ ). The disks were treated with the tyrosine solution in the same way as with the caffeic acid solution.

Treatment 3 times with the tyrosine solution had little effect on the sporulation of the disks infected with the incompatible race, but a little inhibitory effect was found in the disks treated 5 times. However more experiments are needed before a conclusion can be drawn as to whether tyrosine can inhibit the spore production or not.

The disks of Kennebec infected by the race 0 were treated with glucose, glycine, ascorbic acid and cysteine, in the same way as with the phenolic compounds (Tables 3 and 4). Glucose and glycine had little effect on the sporulation of the disks infected by race 0 . Cysteine was inhibitory to sporulation on the disks of both Kennebec and Irish cobbler. Cysteine was slightly toxic to zoospore germination (Table 4). The inhibitory action of the phenolic compounds on zoospore germination at $\mathrm{pH} 5.6$ is shown in Table 6. Chlorogenic acid, guaiacol, hydroquinone, 
caffeic acid and catechol, either by themselves or with ascorbic acid in equimolar concentrations, were less inhibitive to zoospore germination than to spore production on infected slices of Kennebec (Fig 2). The toxicity of chlorogenic acid was almost the same at pH 5.5, 6.0 and 7.0 (Table 5).

Table 3. Effect of some chemicals on sporeproduction on thin disks infected by race 0 of $P$ infestans.

\begin{tabular}{l|l|r|r|r}
\hline \multirow{2}{*}{ Potato var. } & Chemicals & \multicolumn{2}{|c}{$\begin{array}{c}\text { Concentration } \\
\text { (Mol. ) }\end{array}$} \\
\cline { 2 - 5 } & & 0.01 & 0.03 & 0.05 \\
\hline & D-Glucose & $102 *$ & 109 & 101 \\
Kennbec & Glycine & 90 & 88 & 90 \\
(Resistant) & L-Ascorbic acid & 78 & 30 & 30 \\
& L-Cysteine & 22 & 17 & 4 \\
Irish Cobbler & L-Ascorbic acid & 72 & 101 & 112 \\
(Susceptible) & L-Cysteine & 4 & 0 & 0 \\
& & &
\end{tabular}

Remarks:

1) Treatment was done 24 hours after inoculation.

2) *As $\%$ of number of spores produced on the untreated disks infected.

Table 4. Effect of glucose, glycine and cysteine on growth rate of germ tubes of zoospores of $P$. infestans.

\begin{tabular}{c|c|c|c}
\hline \multirow{2}{*}{ Chemicals** } & \multicolumn{3}{|c}{ Mol. } \\
\cline { 2 - 4 } & 0.01 & 0.03 & 0.05 \\
\hline D-Glucose & $136 \% *$ & $147 \%$ & $134 \%$ \\
Glycine & 119 & 108 & 140 \\
L-Cysteine & 67 & 55 & 52 \\
\hline
\end{tabular}

Remarks:

1) *As $\%$ of length of zoospore germ tubes of $P$. infestans in $0.02 \mathrm{M}$ phosphate buffer $\mathrm{pH} 5.6$

2) **Dissolved in $0.02 \mathrm{M}$ phosphate buffer at $\mathrm{pH} 5.6$.

Table 5. Relation between the inhibitory effect of chlorogenic acid on the growth rate of zoospore germtubes of $P$. infestans and $\mathrm{pH}$ of the medium.

\begin{tabular}{l|r|r|r}
\hline \multirow{2}{*}{ Medium } & \multicolumn{3}{|c}{$\mathrm{pH}$} \\
\cline { 2 - 4 } & 5.5 & 6.0 & 7.0 \\
\hline With chlorogenic acid* & $79 * *$ & 77 & 72 \\
Without " & 124 & 125 & 118 \\
\hline
\end{tabular}

Remarks: * $0.03 \mathrm{M}$ chlorogenic acid in 0.02 $\mathrm{M}$ phosphate buffer.

** Length of germtubes in $\mu$.
Caffeic acid had little effect on the growth rate of germtubes of the zoospores (Fig. 3).

Content of phenolic compounds in potato tuber tissues. For analysis of phenolic compounds contained in potato tuber tissue, both varieties with the resistant gene $R_{1}$, Rishiri (high "field resistance") and Kennebec (low "field resistance") were used. Daily changes in total phenolic content in the tissue adjoining the cut surface of the potato tuber are shown in Fig. 4. With the infected tuber tissues of the Rishiri variety 24 hours after infection, the total phenol content was lowest in the superficial infected layer (1-L) and highest in the next tissue layer (2-L). Later the content increased in the superficial layer, becoming the highest as compared with those in the other layers. In the case of tuber disks whose surfaces were not infected, on the contrary, no such distinct increase of phenolic compounds was found in the second layer during the initial period. The phenol content was always highest in the first layer. With the infected tubers of Kennebec, the phenol content was always lowest in the superficial infected tissues (1-L). When the cut tuber of Kennebec was not infected, the change of phenolic content was similar to that found in the uninfected cut tuber tissue of Rishiri. These results may be explained by the fact that race 0 can invade only 2 or 3 celis of Rishiri, but can intrude far deeper with Kennebec. The content of the major phenolic components was determined in potato tuber tissue from the cut surface tissues (about $2 \mathrm{~mm}$ in depth) or Rishiri. Analysis was carried out 14 days after inoculation. The results are shown in Table 7 . As the samples in this case involved the 1 st to 4 th layers, the phenol content was averaged from these layers, resulting in low analytical values. $o$-Diphenols, chlorogenic acid, and 


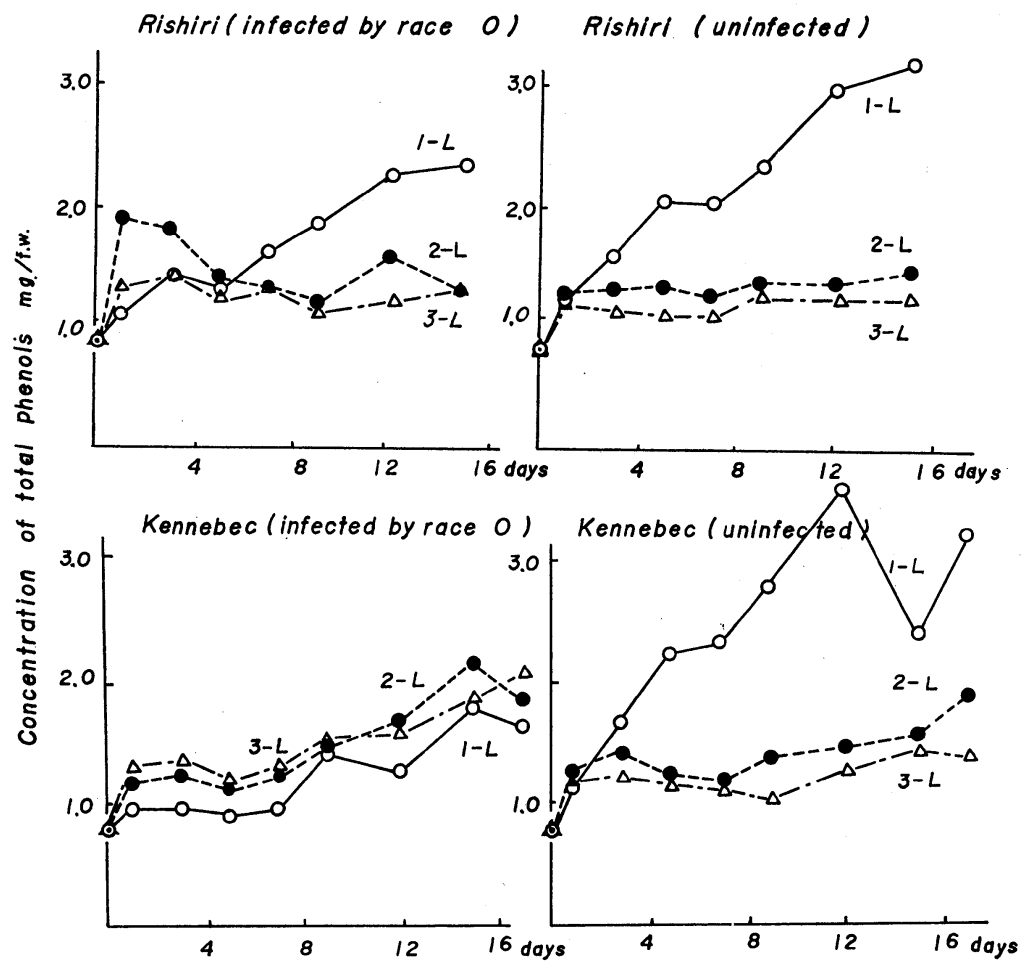

Fig. 4. Total phenol content of potato tuber tissue infected by $P$. infestans.

caffeic acid, were highly augumented by cutting or cutting-and inoculation with race 0 . Their contents, however, were lower in infected tissues than in cut and uninfected ones. Tyrosine and ascorbic acid, on the contrary, were decreased by cutting or infection.

\section{Discussion}

In a previous paper ${ }^{18)}$, it was reported that when tubers of potato varieties with resistant gene $R_{1}$ were cut into disks thinner than $1.5 \mathrm{~mm}$, their inherent resistance was lost, when inoculated with dense zoospore suspension of $P$. infestans. At lower spore concentrations, even the thinnest disks used did not lose their inherent resistance. From these results, it was concluded that about $10 \sim 15$ cells (counted from the infected cells along a straight line vertical to the out surface) were indispensable to complete the defence action when the cut surface was thoroughly inoculated. Determination of phenolic compounds contained in the disks inoculated with compatible and incompatible races showed that infection of thin disks with a dense zoospore suspension of an incompatible race gave the least phenol content. The thinner the disks, the greater was the phenol content. In addition, thin disks showed very weak browning upon heavy infection. However thick ones, showed distinct browning. These results led us to presume that to complete the whole process of resistance of tuber tissue to infection by an incompatible race of $P$. infestans, a considerable number of healthy cells surrounding the infected ones may be needed. One of the roles of these healthy neighbouring cells may be to supply some substances including phenolic compounds to the infected cells to seal off the injured part. If this hypothesis is true, it will be expected that thin disks inoculated with a dense spore suspension of incompatible race of $P$. infestans, may recover their resistance, provided phenolic compounds are supplied after infection. 
Table 6. Effect of phenolic compounds on the germination of zoospores of $P$. infestans either in the presence or absence of ascorbic acid.

\begin{tabular}{c|c|c|c|c|r}
\hline \multicolumn{2}{c|}{ Concentrations of } & \multicolumn{3}{|c}{$\begin{array}{c}\text { Percentage inhibition of growth rate of } \\
\text { zoosporial germtube }\end{array}$} \\
\cline { 1 - 5 } $\begin{array}{c}\text { Ascorbic acid } \\
\text { M }\end{array}$ & $\begin{array}{c}\text { Phenolic } \\
\text { compounds } \\
\mathrm{M}\end{array}$ & $\begin{array}{c}\text { Chlorogenic } \\
\text { acid }\end{array}$ & Guaiacol & Hydroquinone & Catechol \\
\hline $10^{-3}$ & $10^{-3}$ & - & -11 & -8 & -8 \\
$5 \times 10^{-3}$ & $5 \times 10^{-3}$ & - & 15 & 17 & 36 \\
$10^{-2}$ & $10^{-2}$ & 16 & 46 & 41 & 100 \\
$3 \times 10^{-2}$ & $3 \times 10^{-2}$ & 48 & - & - & - \\
$5 \times 10^{-2}$ & $5 \times 10^{-2}$ & 51 & - & 7 & - \\
\hline 0 & $10^{-3}$ & - & -7 & 12 & -9 \\
0 & $5 \times 10^{-3}$ & - & 0 & 35 & 100 \\
0 & $10^{-2}$ & 10 & 45 & - & - \\
0 & $3 \times 10^{-2}$ & 33 & - & - & - \\
0 & $5 \times 10^{-2}$ & 47 & - & - & - \\
\hline
\end{tabular}

The experimental results reported here clearly indicate that the phenolic compounds tested, including chlorogenic acid, either alone or in combination with ascorbic acid in equimolar concentrations, inhibited spore production on thin disks of Kennebec infected by the incompatible race (race 0 ). The brown appearance of diseased spots on treated disks also indicated the recovery of the resistance by phenol treatment. On the contrary, with the susceptible Irish cobbler, treatment of the disks infected by race 0 with the mixture of chlorogenic and ascorbic acid had little inhibitory effect on sporulation. This same concentration strongly inhibited sporulation on disks infected by the incompatible race.

Ascorbic acid alone reduced the sporulation of the Kennebec disks infected by the incompatible race (race 0 ) to the same degree as chlorogenic acid. They did not reduce the sporulation of Irish cobbler disks infected by a compatible race (race 0 ).

The facts that: 1) toxicity of the phenolics tested and ascorbic acid to hyphal growth of the zoosporial germtube was very low as compared with their inhibitory effect on the sporulation of the disks infected with an incompatible race; and 2) chlorogenic acid and ascorbic acid had little effect on the sporulation upon the disks infected by the compatible race (susceptible combination), suggest that phenolic compounds and ascorbic acid may be more toxic to the pathogen in the lesion injured by the hypersensitive reaction. They may also constitute a part of the barrier against disease development. An increase in toxicity of phenolic compounds by enzymatic oxidation has been reported by many authors ${ }^{1,8,10,17,21)}$, although the contrary also has been found ${ }^{8,17)}$. An inhibitive effect of ascorbic acid on the activity of some enzymes has been reported ${ }^{3,11}$. Johnson and Schaal ${ }^{7)}$ suggested that the accumulation of oxidized products of ascorbic acid plays a role in disease resistance.

The results from chemical analysis of phenols contained in the potato tubers were reported by several authors ${ }^{6,12,13,14,15)}$. The analytical results reported here show that the actual content of phenolic compounds in the disks are low (Table 7), as compared with the concentration required for completing the full resistance of the disks to $P$. infestans. The present experimental results suggest that most of the phenolic compounds and ascorbic acid, contained in the tuber tissue, which can be in the quinoid state upon oxidation, may be inhibitive for the development of the parasite in the cells. 
It may not be logical, however, to deduce the amount of phenolic compounds required for completing full resistance on an experimental basis where the solution of the phenolics was supplied for 30 minutes. In diseased tissue, the endogenous phenolic compounds in the neighbouring tissue may permeate the infected cell. When a cell in the potato tuber in infected by a parasite, about 17 healthy cells are involved in the 1 cell area (Fig. 5) which consists of the cells adjacent to the infected one and about 74 in the 2 cells area involving adjacent cells and the ones next to these. If $30 \%$ of the total phenolics contained in each healthy cell are exuded into the infected one, then oxidized and bounded to cellular materials, the concentration accumulated in the infected cell may attain to 5 times (with the 1 cell area) or 20 times (with the 2 cells area) as much as that contained in a single cell. It is reasonable to assume that phenolic compounds may exude into the infected cell from the adjacent healthy cells, since the latter's permeability may be altered by infection. If the above described phenomena really occur, the amount of phenolic compounds contained in the tissue may be enough to lower the velocity of parasite development. The fact that caffeic acid became more efficient in its inhibitory action by repeated treatments of the infected disks seems to support the possibility that the continuous flow of phenolic compounds from the adjacent tissue to the infected lesion can increase the efficiency of the phenolics in retarding disease development.

Hughes and Swain $^{6)}$ found a marked increase in scopolin and scopoletin content in the diseased tissue of the potato late blight, and also found that they are more toxic to $P$. infestans than chlorogenic acid. They suggested thai scopolin and scopoletin may be related to disease resistance. Minamikawa et $\mathrm{al}^{9)}$., however, stated in the case of black rot disease in sweet potato that the content of coumarin derivatives are so low that they do not play an important role in desease resistance. However they increase markedly in the diseased tissue, and are very toxic to Ceratocystis fimbriata. It is reasonable to suppose that these coumarin derivatives play a role in the resistance in cooperation with the other phenolic compounds.

It may well be stated that the common phenolic compounds play a role in disease resistance in conjunction with other factors, such as hypersensitivity, phytoalexins and so on.

Table. 7. Content of phenolic compounds in potato tuber tissue infected by an incompatible race of $P$. infestans or uninfected. (mg/g. fr. wt.)

\begin{tabular}{l|c|c|c}
\hline \hline \multicolumn{1}{c|}{ Treatment } & $\begin{array}{c}\text { Intact* } \\
\text { tuber }\end{array}$ & $\begin{array}{c}\text { Cut and } \\
\text { infected }\end{array}$ & $\begin{array}{c}\text { Cut and } \\
\text { uninfected }\end{array}$ \\
\hline Total pheanols & 0.822 & 1.392 & 2.32 \\
Total O-diphenols & 0.007 & 0.057 & 0.292 \\
Chlorogenic acid & 0.002 & 0.053 & 0.187 \\
Caffeic acid & trace & 0.001 & 0.005 \\
Tyrosine & 0.373 & 0.188 & 0.243 \\
Ascorbic acid & 0.063 & 0.032 & 0.025 \\
\hline
\end{tabular}

Remark: * Central parenchyma tissue.

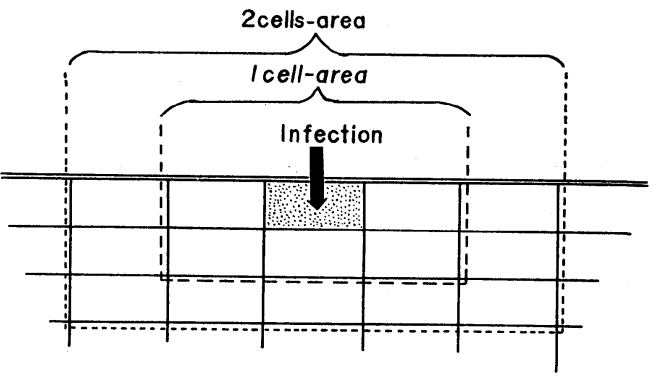

Fig. 5. Diagramatic explanation of the number of healthy cells surrounding a single infected cell. A like number of cells is present one and two layers above and below the plane of the diagram.

The authors express their sincere gratitude to Dr. R. D. Durbin for his valuable advice in preparation of this manuscript. 


\section{Literature Cited}

1. Alberghina F. A. M. (1964). Life Sciences 3: 49-54. Pergamon.

2. Arnow, L. E. (1937). J. Biol. Chem. 531-537.

3. Baruah, P. and T. Swain (1953). Biochem. J. 55: 392-399.

4. Cruickshank, I. A.M. (1963). Ann. Rev. Phytopathol. 1: 351-374.

5. Hiraoka, E. (1955). determination of Vitamin C including stabilizer (in Japanese.) Vitamin (Tokyo) 8: 137-140.

6. Hughes, J.C. and T. Swain (1960). Phytopathol. 50: 398-400.

7. Johnson, G. and L. Schaal (1957). Am. potato J. 34: 200-209.

8. Lyr. H. (1965). Phytopathol. Z. 52: 229-240.

9. Minamikawa, T., T. Akazawa and I. Uritani (1963). Plant Physiol. 38: 413-497.

10. Oku, H. (1960). Phytopathol. Z. 38: 342-354.

11. Rowa, A. W. \& C. E. Weill (1959). Amer. Chem. Soc. 81: 921-924.

12. Rubin. B. A. and E. V. Artsikhovskaya (1964). Ann. Rev Phytopathol. 2: 157-178.

13. Sokolova, V.E. and G. A. soloveva. (1962). Doklady 144: 487-489.

14. Sokolova, V.E. (1964). Biockhim. Pokoy kartofeca plodon i ovoschey, 36 (ed. Nauka, Moskva).

15. Tomiyama, K., N. Takase, R, Sakai, and M. Takakuwa (1956). Res. Bull. Hokkaido Nat1. Agr. Exp. Sta. 71: 32-50.

16. Tomiyama, K. (1955). Ann. Phytopathol. Soc. Japan. 19: 149-154.

17. Tomiyama. K. (1963). Ann. Rev. Phytopathol. 1: 295-324.

18. Tomiyama, K., M. Takakuwa and N. Takase (1958). Phytopathol. Z. 31: 237-250.

19. Tomiyama, K., R. Sakai, Y. Otani and T. Takemori. (1967). On the phenols metabolism in relation to disease resistance of potato tubers. I. P1. \& Cell physiol. (in press).

20. Uritani, I. and T. Akazawa (1959). Alteration of the respiratory pattern in infected plants. Plant pathology. I: $349-390$.

21. Williams, A.H. (1963). Enzyme chemistry of phenolic compounds. (Ed. J. B. Pridham) P. 87-95. Pergamon.

22. Zucker, M. and J.F. Ahrens (1958). Plant. Physiol. 33: 246-249.

\section{和交摘要}

ジャガイモ塊䒱の疫病抵抗性に於けるフェノール化合物の意義について

佐久間勉・冨山宏平

抵抗性遺伝子 $\mathrm{R}_{1}$ をもつジャガイモ塊茎組織を厚さ $0.5 \mathrm{~mm}$ のスライスにして, 非親和性疫病菌レースの 濃厚な胞子液を接種すると, その本来の抵抗性を失なつてしまう（低濃度胞子液で怟抗性を失わない）。 この実験結果から感染部の隣接組織でフェノール化合物その他の物質が生産されて, それが感染部へ転送さ れて疫病菌の進展阻止に役立つものと推定した。（前報告）

もしこの推定が真実ならば抵抗性を失なつた薄片濃厚感染スライスは外部からフェノール化合物を与える ことによつてその抵抗性を回復することが期待される。この点を確めるためにここに報告する諸実験を行な つた。実験結果は上記の推定を証明し，かつこれらのフェノール類は壊死組織でのみ強い菌進展阻止効果を 示し，親和性レースを接種した共生的罹病組織では阻止効果を注とんど示さなかつた。フェノール化合物の 分析結果は非感染ならびに感染組織でその含量が菌進展阻止に必要とされる濃度よりはるかに低いことを示 した。これらの結果は前報でのべた菌の進展を阻止するために約 10〜15 細胞層に及ぶ隣接健全組織を必要 
とし，且つその組織でフェノールが生産されて被害部に沈着するものであろらという推定に一致するもので ある。感染細胞を囲を細胞群からその 展を阻止し始める濃度に達し得ることを理論的に示した。

以上に述べたフェノール化合物という言葉はここでは健全植物に含をれる通常のフェノール化合物の及を 示し,フェノール性ファイトアレキシンおよびクマリン化合物を含まない。ただしファイトアレキシン, ク マリン化合物の抵抗性に拈ける意義を否定するものでは絶対にない。 
Plate I

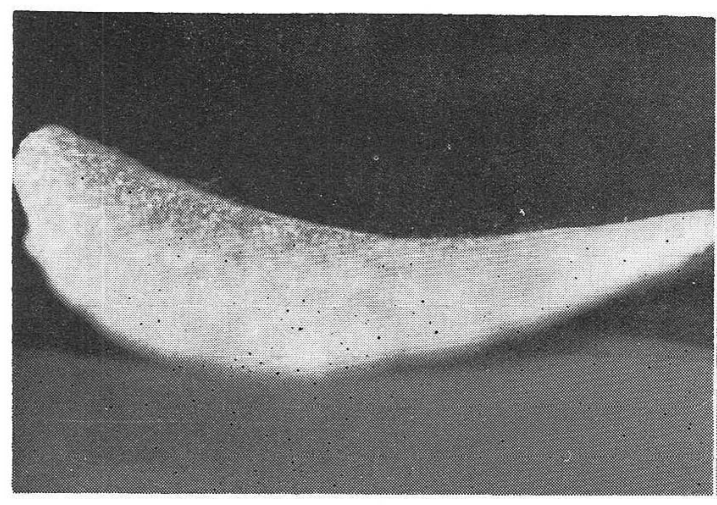

A

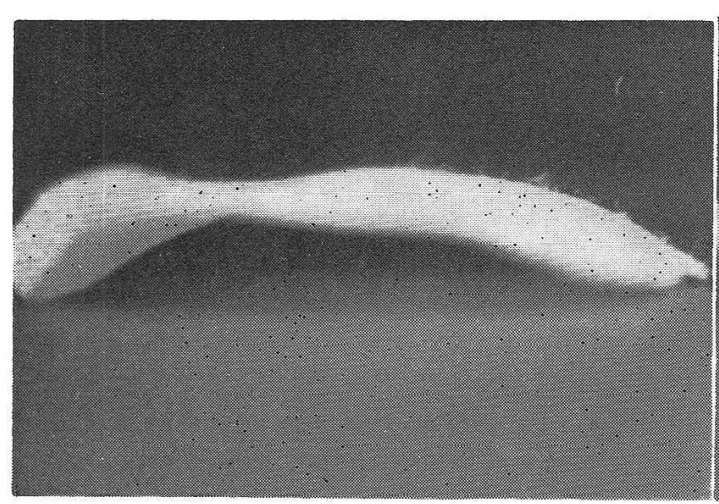

C

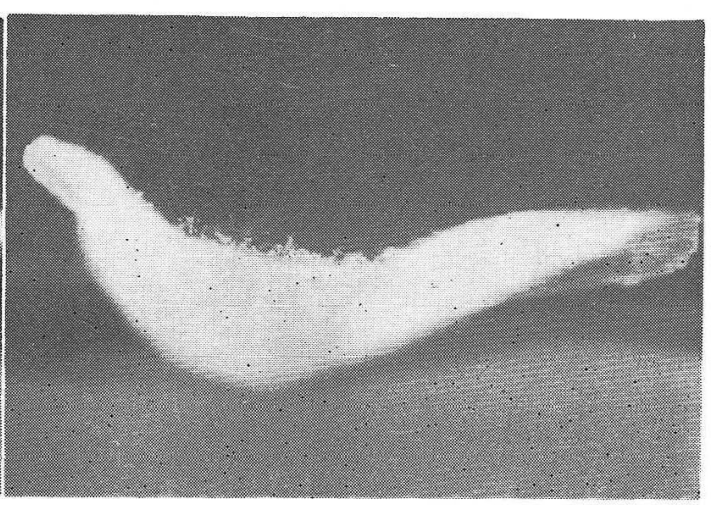

B

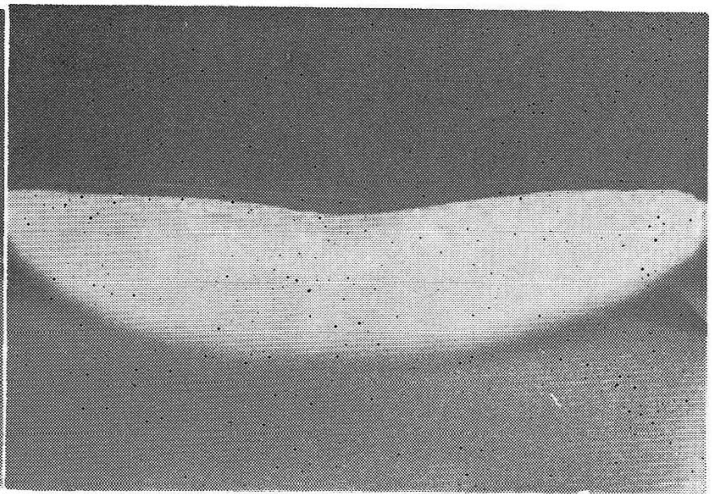

D

\section{Explanation of plate I}

Fig. 6. Sporulation of $P$. infestans on potato tuber disks. (var.: Kennebec)

A. Disk $1 \mathrm{~mm}$ in thickness, inoculated with race $O$, without treatment.

B. Disk $0.5 \mathrm{~mm}$ in thickness, inoculated with race $\mathrm{O}$, without treatment.

C. The same as above, treated with $0.02 \mathrm{M}$ chlorogenic acid and ascorbic acid.

D. The same as above, treated with $0.05 \mathrm{M}$ chlorogenic acid and ascorbic acid. 